\title{
TÜRK HUKUKUNDA NEFRET SUÇLARINA -AVRUPA GÜVENLİK VE İŞBİRLIĞİ TEŞKİLATI TAAHHÜTLERİ ÇERÇEVESINDE- GENEL BİR BAKIŞ
}

\author{
A General Look on Hate Crimes in Turkish Law (Within the Framework of \\ Organization for Security and Co-operation in Europe Commitments)
}

\section{Süleyman ÖZAR*}

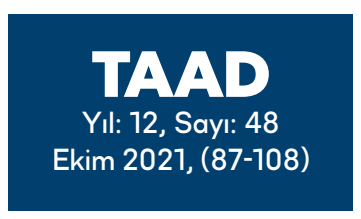

Makale Bilgisi

Geliş Tarihi : 27.05.2021

Kabul Tarihi : 14.09.2021

Makale Türü: Araştırma

\section{$\underline{\text { Article Info }}$}

Received Date: 27.05.2021

Accepted Date: 14.09.2021

Article Type : Research

\section{ÖZET}

Toplumdaki belli gruplara karşı hoşgörüsüzlük ve ön yargıyla işlenen belirli suçlar nefret suçu olarak tanımlanmaktadır. Bu tür fiiller, toplumu bölme, şiddet ve nefret sarmalı yaratma potansiyeline sahip olduğundan, bunlara etkin bir karşıllk verilmesi elzemdir.

Avrupa Güvenlik ve İşbirliği Teşkilatı (AGİT), 2000'li yılların başından itibaren nefret suçlarına kapsamlı bir yaklaşım sergilemektedir. Varşova'da bulunan Demokratik Kurumlar ve İnsan Hakları Ofisi (ODIHR); nefret suçları, nefret söylemi ve ayrımc1lıkla mücadele gibi insani boyuta ilişkin konularla ilgilenen bağımsız bir AGITT kurumudur. ODIHR, nefret suçu düzenlemelerine büyük önem vermektedir.

Ceza normları, toplumsal değerlerin bir yansımasıdır. Nefret suçu düzenlemeleri, bir toplumsal değer olarak eşitlik ilkesini ifade ettiği gibi, aynı zamanda bu değerin gelişmesine de hizmet eder. Türk Ceza Kanunu'na 2005 yılında “Ayrımcılık” adıyla giren ve 2014 y1lında, baz1 unsurlarıly birlikte ismi de "Nefret ve Ayrımcılık" olarak değiştirilen suçun bir nefret suçu olduğu, maddenin gerekçesinde ifade edilmektedir. Bununla birlikte, her ne kadar kanun maddesinde suçun, ayrımc1lı sebeplerine dayalı bir nefretle işleniyor olması aransa da bu bir nefret suçu değildir. Bu nedenle, çalışmamızda nefret suçunu kapsamlı bir şekilde ele alan düzenleme modelinin ortaya konulması amaçlanmaktadır.

Anahtar Kelimeler: Nefret, eşitlik, nefret suçu, nefret söylemi, AGIT, AGITT taahhütleri.

\begin{abstract}
Certain crimes motivated by intolerance and bias towards certain groups in society are described as hate crime. A vigorous response to such crimes is essential, since they have the potential to divide societies, and to create cycles of violence and hatred.

The Organization for Security and Cooperation in Europe (OSCE) has taken a comprehensive approach to hate crimes since the early 2000s. Office for Democratic Institutions and Human
\end{abstract}

Bu makale Etik Kurul İznine tabi değildir.

* Dr., Hâkim, Adalet Bakanlığı Mevzuat Gn. Mdr. Yrd, suleyman.ozar@adalet.gov.tr, https:// orcid.org/0000-0003-0934-9594. 
IIIIIIIIIII

Rights, based in Warsaw, is an independed OSCE body which is primarily concerned with matters falling within the human dimension, such as fighting against hate crimes, hate speech, and discrimination. ODIHR gives great importance to hate crime laws.

Criminal laws are a reflection of society's values. Hate crime laws both express the social value of equality and foster the development of those values.

The crime embodied in the Turkish Penal Code of 2004 under the name of "Discrimination" and later amended to be entitled "Hate and Discrimination" in 2014 is declared to be a hate crime in the preamble to the article. However, although such crime is required to be committed with hate based on discrimination, it is not really a hate crime. Therefore, in this study, it has been aimed to put forward a provision model that effectively addresses hate crimes.

Keywords: Hatred, equality, hate crime, hate speech, OSCE, OSCE commitments.

\section{GíRIŞ}

İnsan onuru; nefret suçu ve nefret söylemlerine karşı alınan hukuki tedbirlerin temel gerekçesini oluşturmaktadır. Bu yönüyle nefret suçu, suça etki eden bir neden olarak yeni bir kavram olsa da ceza normlarının koruduğu hukuksal değer bakımından yeni tanışılan bir olgu değildir. Çünkü insan onur ve haysiyeti, hukuk sistemlerinin ve ceza normunun koruduğu değerlerin başında gelmektedir. Günümüzde bu korumanın alanı ve yöntemi yeniden şekillenmektedir. Çünkü onur ve haysiyete karşı fiiller, insanın var oluşuna ve kimliğine yönelik yeni saldırı biçimleriyle karşımıza çıkmaktadır. 20. yüzyıl sonlarından itibaren bu konunun tüm dünyada tırmanış göstermesi, nefret eylemlerine karşı hukuk düzenlerini de harekete geçirmiştir.

Nefret suçları küresel bir olgu olmakla birlikte, nefret saikinin tanımına ve korunacak karakteristiklerin neler olacağına dair genel bir uzlaşı yoktur. Bununla birlikte, Avrupa Güvenlik ve İşbirliği Teşkilatı'nın (AGİT) suçun tanımına ve soruşturulmasına ilişkin geliştirdiği öneriler, ülkelerin mevzuat tercihlerinde öne çıkmaktadır. AGİT'in üç ana faaliyet alanından biri olan "insani boyut" içerisinde nefret suçlarına ilişkin çalışmalar son yıllarda artarak devam etmektedir. Elbette bu artış, AGİT coğrafyasında nefret suçları ile mücadeleye yönelik politik istekle paraleldir. Bu çalışmalar büyük ölçüde, Demokrasi ve İnsan Hakları Ofisi (ODIHR) tarafından yürütülmektedir.

Ceza hukukumuzda nefret suçları özel olarak düzenlenmemiştir. 2014 yılında TCK' nın 122. maddesinin "Ayırımcılık" olan madde başlığ "Nefret ve ayırımcılık" olarak değiştirilmiş, suçun manevi unsuruna "nefret nedeniyle" şartı getirilmiş ise de, bu değişikliğin uluslararası standartlarda bir nefret suçu düzenlemesi olduğunu söyleyebilmek güçtür.

Çalışmamızda nefret suçları AGİT/ODIHR'in ortaya koyduğu çerçevede ele alınacaktır. Buna göre nefret saikinin içini dolduran 'ön yargı' kavramı ve bunun mağdurun kimliğine, kim olduğuna yönelmesiyle oluşan nefret suçları incelenecektir. Ayrıca, nefret suçu ile nefret söylemi arasındaki farkın ortaya konulmasıyla, mevzuatımız her iki fiil bakımından ayrı ayrı yoklanacaktır. Bu bağlamda, ODIHR'in her yıl yayınladığı ülke raporları konuya karşılaştırmalı bakabilmemizi kolaylaştıran bir kaynak olarak değerlendirilmiştir. Türkiye 
raporu da ülkemizin nefret suçlarıyla mücadelede atması gereken adımları göstermesi bakımından ayrı bir başlıkta ele alınmıştır.

\section{A. AGITT TAAHHÜTLERINNDE NEFRET SUÇU}

\section{AGITT Taahhüdü Nedir?}

AGIT'in karar organlarınca alınan bütün kararlara AGITT taahhütleri adı verilmektedir. $\mathrm{Bu}$ taahhütlerin hukuki bağlayıcılığı bulunmamakla birlikte, siyasi bağlayıcılı̆̆ 1 söz konusudur. ${ }^{1} 57$ katılımcı devletle en büyük bölgesel güvenlik örgütü unvanını elinde bulunduran örgütte bütün kararlar oydaşmayla alınmaktadır. ${ }^{2} \mathrm{Bu}$ durum karar alınmasını zorlaştırmakta, ancak alınan kararın uygulanma olasılığını ise artırmaktadır. Öte yandan, AGİT belgelerinin içeriğine hukuki zorunluluk tanımamış olması, taahhütlerin uluslararası teamül kuralı haline gelebilmesini engeller. ${ }^{3}$

Örgütün üç karar organı bulunmaktadır. Bunlar; zirve, bakanlar konseyi ve daimi konseydir. En önemli ve en üst düzey karar organı Devlet ve Hükümet Başkanları Zirvesidir (Summit). Bugüne kadar Paris (1990), Helsinki (1992), Budapeşte (1994), Lizbon (1996), İstanbul (1999) ve Astana Zirvesi (2010) yapılmıştır. Zirveler düzenli ve sık aralıklarla yapılmadığından, her yıl Aralık ayında dönem başkanı ülkede yapılan Bakanlar Konseyi toplantısı, en önemli karar organı haline gelmiştir. Daimi Konsey ise AGIT'in düzenli politik istişare ve kurumsal karar organıdır. 1992 Bakanlar Konseyi kararı ile kurulan daimi konsey, dönem başkanı ülkenin AGİT nezdindeki daimi temsilcisi tarafından yönetilir. ${ }^{4}$

Sekretaryası Viyana'da bulunan AGIT'in dışında teşkilatlanan ve bağımsız olarak faaliyet gösteren AGİT kurumları da bulunmaktadır. Faaliyet raporlarını mutat olarak Daimi Konseye sunan bu kurumlar; Demokratik Kurumlar ve İnsan Haklar1 Ofisi (Office for Democratic Institutions and Human RightsODIHR), Milli Azınlıklar Yüksek Komiserliği ve Medya Özgürlüğü Temsilciliğidir. Nefret suçuna ilişkin saha çalışmaları, eğitim ve veri toplama faaliyetleri ODIHR tarafindan yerine getirilmektedir.

\section{Nefret Suçuyla Mücadele Yasalarını Teşvik}

Nefret suçlarıyla uluslararası düzeyde mücadele eden başlıca kuruluşlar, Birleşmiş Milletler (BM) İnsan Hakları Komitesi, BM "Irk Ayrımcılığının Ortadan Kaldırılması" Komitesi (CERD), Avrupa Konseyi "Irkçılık ve

Sertif Demir, “Dünden Bugüne Avrupa Güvenlik ve İşbirliği Teşkilatı”, Güvenlik Stratejileri Dergisi, 6/11, 2010, s. 30.

2 “OSCE Rules of Procedure" (AGIT Usul Kurallar1) http://www.osce.org/mc/22775 (sgt. 15.05.2021)

3 Jale Civelek, "Helsinki Son Senedi, Paris Şartı ve AGİT", Avrupa Araştırmaları Dergisi, C. 14 S. 12, 2006, s. 6.

$4 \mathrm{https}: / /$ www.osce.org/whatistheosce/factsheet (sgt.15.5.2021) 
IIIIIIIIII!

Hoşgörüsüzlüğe Karşı Avrupa Komisyonu” (ECRI), Avrupa Birliği (AB) Temel Haklar Ajansı (FRA) ve AGİT'tir. Bu kuruluşlar, nefret suçlarını 1rkçılık ve yabancı düşmanlığının ötesinde daha geniş bir zeminde ele almaktadır. ${ }^{5}$

AGIT'in bu sahadaki çabalarına geçmeden önce AB ve Avrupa Konseyi'nin mevzuat önerilerine değinmek istiyoruz. Avrupa Konseyi Bakanlar Komitesi, 1997 tarihli R (97) 20 sayılı kararında üye ülkelerin ceza mevzuatında ırkçı ve yabancı düşmanı saiklerle ortaya çıkan nefret söylemlerinin suç olarak düzenlenmesi yönünde tavsiyede bulunmuştur.

ECRI de, 1996 tarihinden itibaren mutat olarak ırkçılık ve ayırımcılığa karşı ortak politika standartlarını belirleyen "Genel Politika Tavsiyeleri"

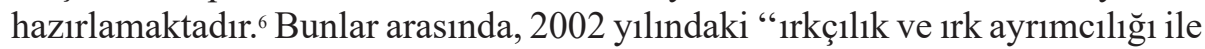
mücadele için ulusal mevzuat" başlıklı 7 numaralı Genel Politika Tavsiyesi'nin 2007 revizyonu, mevzuat önerisi içermektedir. Bu kapsamda, Konsey üyesi ülkelere bir suçun ırkçı saiklerle işlenmesi halinin cezayı ağırlaştıran bir nitelikli hal olarak düzenlenmesi tavsiye edilmiştir. ${ }^{7} 2015$ yılındaki 15 numaralı Politika Tavsiyesi ise nefret söylemi ile mücadeleye yönelik tedbirleri içermektedir. ${ }^{8}$

Görüldüğ̈̈ üzere nefret saikiyle mücadele, genelde nefret 'söylemi' bağlamında gündeme gelmektedir. Konuyu nefret 'eylemi' bağlamında etraflıca tartışan ve takip eden kurum, AGIT'tir.

AGIT/ODIHR, nefret suçlarıyla mücadele kapsamında üç tür faaliyet göstermektedir. Bunlar; (1) mevzuat değişikliklerine pratik rehberlik ve teşvik çalışmaları, (2) seminer ve çalıştaylarla kapasite artırımı ve eğitim, (3) nefret suçlarına ilişkin düzenli olarak veri toplama ve raporlamadır. ${ }^{9} \mathrm{Bu}$ faaliyetler, AGİT katılımcı devletlerinin üç temel taahhüdüne dayanmaktadır: Mevzuatta nefret suçlarına yer vermek, nefret suçlarını etkili soruşturmak ve bu suçları sağlıklı bir şekilde raporlayarak paylaşmak.

Nefret suçları kavramı AGIT'’in gündemine ilk olarak 2003 yılının Aralık ayında Maastricht'te yapılan Bakanlar Konseyi toplantısında doğrudan doğruya girmiş ve bu toplantıda katılımcı devletler nefret suçlarının yarattığı tehlikeleri kabul ederek, bu suçlarla mücadele için gerekli adımların atılması konusunda görüş birliği içerisinde olduklarını beyan etmişlerdir. ${ }^{10}$ Atina 2009

5 Hate Crime Recording and Data Collection Practice Across the EU, European Union Agency for Fundamental Rights, Luxembourg 2018, s. 14.

6 https://www.coe.int/en/web/european-commission-against-racism-andintolerance/ecri-standards (sgt. 18.05.2021)

7 https://rm.coe.int/ecri-general-policy-recommendation-no-7-revised-on-nationallegislatio/16808b5aae (sgt. 18.05.2021)

$8 \mathrm{https}: / / \mathrm{rm} . c 0 e . i n t /$ ecri-general-policy-recommendation-no-15-on-combatinghate-speech/16808b5b01 (sgt. 18.05.2021)

9 https://hatecrime.osce.org/odihrs-capacity-building-efforts (sgt. 18.05.2021)

10 Hasan Sınar, "Türk Hukukunda Nefret Suçlarına İlişkin Yasal Düzenleme Çalışmaları”, Marmara Üniversitesi Hukuk Fakültesi Hukuk Araşstrmaları Dergisi, 19 / 2, Aralık 2013, s. 1280. 
Bakanlar Konseyi'nde kabul edilen "nefret suçlarıyla mücadele” başlıklı 9/09 sayılı karar, bu alandaki ilk müstakil taahhüttür. Bunlara ek olarak, ODIHR'ın yayınladığı kılavuz ilkeler ve mevzuat önerileri de nefret suçlarının tanımına ilişkin önemli bilgiler içermektedir. 2009 yılında yayımlanan "Nefret Suçu Yasaları Pratik Kılavuz" bu alanda yapılmış en önemli çalışmalardan biridir.

\section{Nefret Suçu Tanımı}

AGIT/ODIHR doktrinine göre ortada bir nefret suçunun bulunduğuna karar verebilmek için, suç teşkil eden bir eylemin nefret saikiyle işlenmiş olması gerekir. ${ }^{11}$ Bir suçun nefret suçu niteliğine bürünebilmesi, önce nefret saikine sonra da bu saikle işlenen temel bir suça ihtiyaç duyar. Temel suç yoksa nefret suçu da yoktur. ${ }^{12}$ Nefretle işlenen suçun hangileri olabileceği ülkeden ülkeye değişiklik gösterebilir, ama her halükârda nefret nedeniyle ortaya çıkan icrai veya ihmali bir davranış ve bu davranışın suç olarak düzenlenmiş olması lazımdır. Dolayısıyla nefret suçlarında failin belirli bir saik ya da amaçla hareket etmesi (eski Türk Ceza Kanunu terminolojisiyle "özel kast"ın bulunmasi) şarttır.

Salt nefret etmek ya da soyut nefret suç değildir. Bir irk, milliyet, etnik köken, dil, renk, cinsiyet, cinsel yönelim, yaş, engellilik ve benzeri sebeplerden dolayı duyulan ön yargının faili bir suç işlemeye yöneltmiş olması gerekir. ${ }^{13}$ ODIHR, 've benzeri sebepler' diyerek hangi özellik ya da sıfatların ön yarg1 konusu olabileceği noktasında güncel durumlara ve lokal sorunlara esneklik payı bırakmıştır. Örnek vermek gerekirse, AGİT coğrafyasındaki bütün nefret suçu yasalarında "irk", korunan kategori kapsamındadır. Bazı ülkeler cinsiyet, cinsel yönelim ve engellilik gibi kategorileri içerir. Daha az olarak da, bazı nefret suçu yasaları eğitim, meslek, siyasi bağlantı veya ideoloji gibi kategorileri korur. ${ }^{14}$ Sonuçta yasa koyucu hangi özelliklerin burada yer alacağını kesin ve belirli bir şekilde ifade etmelidir. Ucu açık bir şekilde alanı hayli genişleyen bir nefret suçu kategorisi nefret kavramını anlamsızlaştıracağ 1 gibi ${ }^{15}$ kanunilik ve dolayısıyla hukuk güvenliği ilkelerine de aykırı olacaktır.

Nefret suçuna esas alınacak karakteristiklerin seçilmesi konusunda eşitlik ilkesi bir an olsun ihmal edilmemelidir. Yoksa kanun koyucu kendi içinde çelişmiş ve başka bir yönden ayrımcılı̆ga kendisi yol açmış olacaktır. ${ }^{16}$

\footnotetext{
Understanding the Needs of Hate Crime Victims, OSCE/ODIHR, Warsaw 2020, s. 8.

Hate Crime Laws: A Practical Guide, OSCE/ODIHR, Warsaw 2009, s. 16.

13 Combating Hate Crimes in the OSCE Region, An Overview of Statistics, Legislation and National Initiatives, OSCE/ODIHR, Warsaw 2005, s.12.

14 Hate Crime Laws, s. 37.

15 Gökçe Serim Çiçek, Türk Ceza Kanunu'nda Nefret ve Ayrımcılık Suçu, Ankara 2021, s. 67.

16 Asuman Aytekin İnceoğlu, "Nefret Suçu Kavramı ve Türk Ceza Mevzuatı Açısından Değerlendirilmesi”, Nefret Söylemi ve/veya Nefret Suçları, Der: Yasemin İnceoğlu, İstanbul 2012, s. 114.
} 
IIIIIIIIII!

Nefretle işlenen her suç nefret suçu olarak kabul edilmemelidir. Kelimenin sözlük anlamıyla nefret, nefret suçlarının saiki için yeterli bir kavram değildir. Failin kanunda belirtilen özelliklerden birine duyduğu nefretin kaynağı 'ön yargı' veya düşmanlık olmalıdır. Bu nedenle karşılaştırmalı hukukta bu suça "ön yarg1 saikli suçlar" (bias-motivated crimes) veya "ayrımc1 suçlar" (discriminatory crimes) gibi isimler de verilmektedir. ${ }^{17}$ Nefret suçunu işleyen fail, mağdurdan bizzat nefret etmiyor ve hatta onu tanımıyor bile olabilir. Bu noktada, bir suçu nefret suçu haline getiren ölçüt, failin mağdurun dahil olduğu topluluk özelliklerine karşı ön yargı taşıması ve bu ön yargıyla bir ceza normunu ihlal etmesidir. ${ }^{18}$

Nefret suçunun yöneldiği mağdurun, ön yarg1 duyulan unsura sahip olup olmadığı, mağdurun o unsurun temsil edildiği gruba ait olup olmadığ1 hususlarının suçun oluşumuna etkisi tartışmalıdır. Bizim de katıldığımız görüşe göre burada önemli olan, failin mağduru nasıl gördüğüdür; mağduru o grupta konumlandırması veya sanması yeterlidir. ${ }^{19}$ Aynı şekilde, o gruptan olmasa da sadece destek olduğu için mağdurun seçilmesi halinde de nefret suçu oluşmuş sayılmalıdır. ${ }^{20}$

Nefret suçunun maddi konusu bir insan veya bir topluluk olabileceği gibi, belli bir gruba has eşya, ibadethane, okul gibi maddi öğeler de olabilecektir. Nefret saikinin ortaya çıkmasında maddi konunun kim veya ne olduğundan ziyade, neyi temsil ettiği önemlidir. Bu nedenle bu suçlar sembol suçlarıdır.21 Çünkü, fail mağdura 'bu haliyle' topluma dahil olma hakkına sahip olmadığına yönelik bir mesaj vermektedir. ${ }^{22} \mathrm{O}$ halde hukuk düzeni de bu eylemi ayrı ve daha ağır cezalandırarak mevcut ve muhtemel faillere bu mesajı iade etmelidir.

\section{Nefret Suçu-Nefret Söylemi Ayrımı}

ODIHR, nefret suçu ile nefret söyleminin aynı anlama gelmediğinin, bunların farklı hukuksal kavramlar olduklarının altını önemle çizmektedir. Nefret söyleminin de gerisinde ayrımcı, ön yargılı bir bakış açısı olabilir ama bu söylemler ifadeden ibarettir. Nefret saikinin sürüklediği temel suç kategorisi eksiktir. ${ }^{23} \mathrm{Bu}$ durum nefret söyleminin (hate speech), nefret suçu (hate crime)

17 Prosecuting Hate Crimes, OSCE/ODIHR, Warsaw 2014, s. 20.

18 Prosecuting Hate Crimes, s. 21.

19 Hate Crimes in the OSCE Region-Incidents and Responses, Annual Report for 2007, Warsaw 2008. Aynı doğrultuda değerlendirmeler için bkz. Ulaş Karan, "Nefret Suçlarından Ne Anlıyoruz?", Nefret Suçları ve Nefret Söylemi, Hrant Dink Vakfı Yayınları, İstanbul 2010, s. 57.

20 Serim Çiçek, s. 67.

21 Hate Crime Laws, s. 17.

22 Preventing and Responding to Hate Crimes, A resource guide for NGOs in the OSCE region, OSCE/ODIHR, Warsaw 2009, s. 17.

23 Prosecuting Hate Crimes, s. 22. 
olmasını önlemekte, nefret söyleminin ayrı bir suç olarak düzenlenmesi de bu sonucu değiştirmemektedir.

Nefret suçunda, zaten var olan bir temel suçun nefret saiki ile işlenmesi söz konusudur. Aşağıda ayrıntılı olarak ele alınacağı üzere, nefret söyleminde ise bu söylemin kendisi (adeta bizatihi nefret) suç olarak düzenlenmiştir.

Avrupa Konseyi Bakanlar Komitesi, R (97) 20 say1lı tavsiye kararında nefret söylemini şöyle tanımlanmıştır: "Nefret söylemi kavramı, ırkçı nefreti, yabancı düşmanlığını, Yahudi düşmanlı̆̆ını veya azınlıklara, göçmenlere ve göçmen kökenli insanlara yönelik saldırgan ulusalcılık ve etnik merkezcilik, ayrımcılık ve düşmanlık şeklinde ifadesini bulan, dinsel hoşgörüsüzlük dâhil olmak üzere hoşgörüsüzlüğe dayalı başka nefret biçimlerini yayan, kışkırtan, teşvik eden veya meşrulaştıran her türlü ifade biçimini kapsayacak şekilde anlaşılacaktır. Bu anlamda nefret söylemi, muhakkak belirli bir kişiye veya gruba yönlendirilmis yorumları kapsamaktadır. "24

İfadenin ya da söylemin suça yol açması, nefret söylemi ile ifade özgürlüğü arasındaki gerilimi ortaya çıkarır. Söylemin ifade özgürlüğü içinde kalıp kalmadığ 1 her olayda kendi bağlamı içerisinde değerlendirilmelidir. Nefret söylemi, ifade özgürlüğüne müdahaleyi meşru kılar, ancak neyin nefret söylemi olduğu konusunda demokratik toplum gereklerini hesaba katarak titiz davranılmalıdır. ${ }^{25}$ Avrupa İnsan Hakları Mahkemesi, konuyla ilgili olarak ortaya çıkan içtihatlarında, ilk olarak, taraf devletlerin işlenen bir suçun olası bir nefret saikiyle işlenip işlenmediğinin etkin bir biçimde soruşturulması noktasında pozitif bir yükümlülüğü olduğunun altını çizmektedir. ${ }^{26}$ Mahkeme, AİHS'in temellerini oluşturan değerlere yönelik her türlü ifadede olduğu gibi hoşgörüsüzlük üzerine kurulu kini yayan, haklı gösteren, buna teşvik eden ve ilerleten ifade biçimlerinin AİHS'in 10. maddesi ile sağlanan korumadan yararlanamayacağını açıķ̧a ve kuşkuya yer bırakmayacak biçimde ifade etmektedir. ${ }^{27}$ Diğer bir deyişle, bu tür ifadelere yönelik müdahaleler, AİHS m. 10 'un ihlali olarak değerlendirilmemektedir.

Anne Weber, Nefret Söylemi, Çev: Metin Çulhaoğlu, Avrupa Konseyi Yayınları, 2009, s. 4.

Nefret söyleminin ifade özgürlüğü karşısındaki konumunu değerlendiren çalışmalar için bkz. Aras Türay, "Nefret Söylemi ve İfade Özgürlüğü Arasındaki İlişkiye Yönelik Görüşlerin Kısa Bir Değerlendirmesi”, Suç ve Ceza Dergisi, s. 139-160, 2018/2; Oktay Uygun, "Nefret İfadesi ve İfade Özgürlüğü", Galatasaray Üniversitesi Hukuk Fakültesi Dergisi, C. 5 S. 1, s. 7-25, Ocak 2008; Elif Küzeci, “AİHS’ in 10. Maddesi Işı̆̆ında Nefret İçerikli ve Irkçı Nitelikteki Düşünce Açıklamaları", TBB Dergisi, S. 71, Temmuz 2007; Özcan Özbey, “Avrupa İnsan Hakları Sözleşmesi Işı̆ğında İfade Özgürlüğü Kısıtlamaları”, Ankara Üniversitesi Hukuk Fakültesi Dergisi, S. 62, s. 93-146, Mayıs 2013; Cengiz GülSeher Çakan, "AİHM Kararları Işı̆̆ında Nefret, Şiddet Ve Müstehcen İçerikli Söylemler Bakımından İfade Özgürlüğünün Sınırlandırılması”, ERÜHFD, C. XIII, S. 1, s. 365-410, 2018; Freedom of Expression and Hate Speech, OSCE/ODIHR, Skopje 2013.

26 Aİ̈HM, Balsyté-Lideikiené/Litvanya, Başvuru No: 72596/01, 04.11.2008.

27 AİHM, Gündüz/Türkiye, Başvuru No: 35071/97, 14.12.2003. 
IIIIIIIIIII-

Nefret söylemine müdahalenin Sözleşme'yi ihlal etmemesi, iki temele dayanmaktadır. Birincisi, nefret söylemi, temel hak ve özgürlükleri yok etmeye yönelik olarak hakkın kötüye kullanımıdır; ikinci olarak, nefret içerikli ifadeler diğer hak ve özgürlükler ile çatışmaktadır.$^{28}$ Nefret söylemine müdahale edilmemesi, bu söylem ile hedef alınan kişi veya grubun varlığına yönelik saldırılara yol açabilecek bir durumdur.

O halde nefret söylemini, rrk, etnik köken, cinsiyet, cinsel yönelim, engellilik gibi özelliklerden bahisle bir kişiye ya da gruba yönelik düşmanca veya saldırgan ya da aşağılayıcı ifade olarak tanımlayabiliriz. Nefret söylemiyle, hedef alınan kişi veya gruba, benliklerinin reddedildiği, toplumun geri kalanıyla eşit şekilde yaşayamayacağı ve hak rejiminin sağladığı korumada birer istisna oldukları yönünde bir mesaj verildiğini söylemek abartılı olmayacaktır. ${ }^{29} \mathrm{Bu}$ söylemle hem insan onuruna hem de şu ya da bu topluluğun demokratik toplum içindeki hukukuna saldırılmış olmaktadır.

Nefret söylemi, düşünce açıklaması olsa da, nefret suçuna giden yolun ilk durağ 1 olabilir. ${ }^{30}$ ODIHR'in nefret söylemi ile nefret suçu arasında gözettiği ayrım da bu noktada başka bir anlam kazanır. Bu ikisinin ayrı ayrı raporlanması, verimli bir sebep, sonuç ve etki analizi için faydalı olacaktır.

\section{ODIHR Nefret Suçu Ülke Raporları}

AGITT katılımcı devletlerinin taahhütlerinden biri de "nefret suçlarına dair kolluk kuvvetlerine ihbar edilen, kovuşturulan ve hüküm verilen vaka sayılarını içeren yeterince ayrıntıl1, güvenilir, sürdürülebilir ve kamuya açılanabilir veri ve istatistik toplamak" şeklindedir. ${ }^{31}$ Gerçekten, nefret suçlarıyla ilgili verilerin toplanması ve yayımlanması, bu eylemlerle mücadele çabalarının önemli bir parçasıdır. Nefret ve ön yargı sorunuyla yüzleşmek için, yerel ve ulusal yetkililerin ve kamuoyunun sorunun gerçek doğasını, kapsamını ve toplum için yarattığ 1 tehdidi bilmesi gerekmektedir. ${ }^{32}$

ODIHR, 2006'dan bu yana devletlerin nefret suçları üzerine sundukları bilgileri toplamakta ve bunları yıllık raporunda yayımlamaktadır. Kurumun internet sitesinden ${ }^{33}$ takip edilebilecek bu raporlarda, istatistiki verileri gönderen ülke sayısının ve veri miktarının her geçen yıl arttığı görülmektedir. $\mathrm{Bu}$ raporlarda takibi yapılan, haklarında veri toplanan nefret kategorileri

28 Timur, Demirbaş, "Nefret Söylemi ve Nefret Suçları", Dokuz Eylül Üniversitesi Hukuku Fakültesi Dergisi, Prof. Dr. Şeref ERTAŞ’a Armağan, Cilt:19, Yı1: 2017, s. 2701.

29 Demirbaş, s. 2696; Köksal Bayraktar, "Nefret ve Ayrımc1lı Suçu”, Yeditepe Üniversitesi Hukuk Fakültesi Dergisi, Cilt: XIII, Say1: 1, Y11: 2016, s. 73.

30 Freedom of Expression and Hate Speech, s. 35.

31 AGIT 9/09 No'lu Bakanlar Konseyi Kararı, Atina, 1-2 Aralık 2009. https://www.osce.org/ files/f/documents/d/9/40695.pdf (sgt. 16.05.2021)

32 Preventing and Responding to Hate Crimes, s. 37.

33 https://hatecrime.osce.org/ (sgt. 16.05.2021) 
şunlardır: Irkçılık ve yabancı düşmanlığı, antisemitizm, roman ve sintilere, Müslümanlara, Hıristiyanlara, diğer inanç gruplarına, cinsel kimlik ve cinsel yönelime, diğer gruplara (cinsiyet, engellilik, yaş) karşı ön yargı.

ODIHR, resmi verileri her ülkenin bildirdiği irtibat kişi ve kurumlarından almaktadır. Türkiye'de bu irtibatı Adalet Bakanlığı İnsan Hakları Daire Başkanlığ1 yürütmektedir. Ofis, tüm ülkelere nefret suçu düzenlemelerinin yapılmas1 tavsiyesinde bulunurken, ülke raporlarında, bir yasal düzenleme olup olmamasından bağımsız olarak nefret suçu kavramına uyan eylemlere ilişkin gayrıresmi verileri de paylaşmaktadır. ${ }^{34}$

ODIHR ülke raporlarına bakıldığında, nefret suçu kayıtları bakımından ülkeler şu şekilde tasnif edilebilir:

Düzenli veri ileten ülkeler: Türkiye, ABD, Almanya, İngiltere, Fransa, İtalya, Belçika, Avusturya, Litvanya, Polonya, Çek Cumhuriyeti, İsveç, İsviçre, Norveç, Danimarka, Portekiz, Ukrayna, Estonya, Litvanya, Finlandiya, İzlanda, Macaristan, Yunanistan, Slovakya, Bulgaristan, Hırvatistan, Kibris, Andorra, İrlanda, Karadağ, Kanada, Gürcistan, Romanya, Surbistan.

Düzenli olarak veri bildirmeyen ülkeler: Arnavutluk, Azerbaycan, Belarus, Bosna, Slovenya, Türkmenistan, Tacikistan.

Kolluk tarafindan nefret suçu kaydı tutulmayan ülkeler: Türkiye, Rusya Federasyonu, Surbistan, Malta, Lihtenştayn, Lüksemburg, Romanya, San Marino, Moldova, Monako, Kuzey Makedonya, Ermenistan, Kazakistan, Kırgızistan, Moğolistan, Özbekistan, Tacikistan, Türkmenistan.

Nefret suçları istatistiklerini kamuoyuyla paylaşan ülkeler: ABD, İngiltere, Fransa, Avusturya, Kanada, Çek Cumhuriyeti, Hollanda, İsveç, İsviçre, Norveç, Danimarka, Polonya, Estonya.

\section{Nefret Suçu Düzenlemeleri}

AGIT'in nefret suçlarının önlenmesine ilişkin rehber çalışmalarında, nefret saiki ile işlenen suçların ceza mevzuatlarında "cezayı ağırlaştıran nitelikli hal veya bağımsız suç" olarak düzenlenmesi çağrısında bulunulmaktadır. Bu çağrıların genellikle olumlu kabul gördüğü AGİT coğrafyasında, bugün 53 ülkenin mevzuatında nefret suçu düzenlemeleri bulunmaktadır.

Ceza kanunlarında nefret suçlarına yer verirken; genel ağırlatıcı neden olarak düzenlemek veya ilgili suçun altında ağıllatıcı neden olarak ayrı ayrı düzenlemek ya da özel hükümlerde nefret suçunu müstakil bir suç olarak düzenlemek şeklinde üç yöntemden söz edilebilir. Bunların dışında, özel ceza kanunu düzenlemelerini de bir diğer düzenleme yöntemi olarak belirtebiliriz.

34 https://hatecrime.osce.org/infocus/2019-hate-crime-data-frequently-asked-questions (sgt. 16.05.2021) 
IIIIIIIIII!

ODIHR 2020 ülke raporlarını ${ }^{35}$ incelediğimizde şöyle bir sınıflandırma yapilabilir:

Genel Ceza artırımı yapan ülkeler: Almanya, Fransa, Danimarka, Litvanya, Bosna-Hersek, Kıbrıs, İsveç, Finlandiya, Yunanistan, Arnavutluk, Azerbaycan, Lihtenştayn, Malta, Kuzey Makedonya, San Marino.

Bazı suçların altında ceza artırımı: Belçika, Macaristan, Portekiz, İzlanda, Norveç, Slovakya, Slovenya, Kırgızistan, Moğolistan,

Hem genel hem özel artırım: Rusya Federasyonu, Sirbistan, Litvanya, Bulgaristan, Hirvatistan, Çek Cumhuriyeti, Andorra, Ermenistan, Ukrayna, Belarus, Moldova, Karadağ, Lüksemburg, Kazakistan, Tacikistan, Türkmenistan, Özbekistan.

Özel nefret suçu: Estonya, Polonya, Hollanda.

Genel artırım ve özel ceza kanunu: ABD, İngiltere, İspanya, Avusturya, Kanada, Gürcistan, İtalya, Romanya.

Nefret Suçu düzenlemesi olmayan ülkeler: İrlanda, Monako, İsviçre. ${ }^{36}$

Bu bağlamda bazı ülkelerden düzenleme örnekleri vermenin yararlı olacağ 1 düşüncesindeyiz:

Fransa'da 2003 y1lında kabul edilen düzenlemeyle, bir kimsenin gerçek veya varsayllan etnisite, milliyet, ırk ve din gibi karakteristik özellikleri nedeniyle saldırıya uğraması halinde ceza arttırımı öngörülmüștür. Aynı yıl yapılan değişiklikle, cinselyönelim de nefret suçu düzenlemesindekorunmaya başlamıştır. 2004 yılında nefret suçlarının kapsamı tehdit, hırsızlık ve yağma suçlarını da kapsayacak şekilde genişletilmiştir. 2017 yılında yapılan değişiklikle, yukarıda belirtilen karakteristikler kapsamında nefret saiki bütün suçlara uygulanabilecek şekilde genel ceza artırımı sebebi olarak düzenlenmiştir. ${ }^{37}$

Belçika'da 2007 değişikliğiyle kasten öldürme, kasten yaralama, cinsel saldırı, yağma, kundaklama, mala zarar verme, hürriyetten yoksun kı1ma, yardım ve bildirim yükümlülüğünün ihlali ile iftira suçlarında nefret, düşmanlık ya da hakir görme saiki, nitelikli hal olarak düzenlenmiştir. Bu saikler şu karakteristiklere yöneldiğinde ilgili suçlarda ceza artırımı uygulanır: Yaş, renk, nesep, milli ya da etnik orijin, cinsiyet, cinsel yönelim, medeni hal, doğum, servet, yaş, din ya da inanç, sağglk, engellilik, fiziksel özellik. ${ }^{38}$

35 Makalenin yazım tarihindeki en güncel rapor 2020 raporu olup, bu rapordaki bilgiler 30 Nisan 2019-30 Nisan 2020 tarihleri arasına ilişkindir. Halihazırda ODIHR, 16 Kasım 2021'de yayınlayacağını duyurduğu yeni rapor için veri toplamaya devam ettiğini paylaşmaktadır. (https://hatecrime.osce.org/civilsociety 16.05.2021)

36 İsviçre' de ayrımcılık ve nefret söylemi suçları bulunmakla birlikte, ODIHR standartlarında bir nefret suçu düzenlemesi yoktur. https://hatecrime.osce.org/switzerland

$37 \mathrm{https} / /$ www.legislationline.org/legislation/section/legislation/topic/79/country/30 (sgt. 18.05.2021)

$38 \mathrm{https}: / /$ www.legislationline.org/topics/country/41/topic/4/subtopic/79 (sgt. 18.05.2021) 
Hollanda'da Ceza Kanunu'nda 2007 değişikliği ile bir kişiye veya mal varlığına karşı $ı r k$, din, inanış, cinsiyet, heteroseksüel veya homoseksüel yönelim, fiziksel veya zihinsel engellilik nedeniyle şiddet uygulanmasi 1 yıla kadar hapis cezası ile cezalandırılmaktadır. Fiilin birden fazla kişi birlikte işlenmesi halinde ceza iki katına çıkmaktadır. ${ }^{39}$

Almanya'da ceza kanununun genel hükümlerinde yapılan 2015 değişikliği ile fiilin ırkçı, yabancı düşmanı veya insan onurunu hedef alan özelliklerinin araştırılması ve ceza tayininde dikkate alınması düzenlenmiştir. ${ }^{40}$

Danimarka'da ceza kanununda yapılan 2004 değişikliğiyle suçun etnik köken, dini inanış, cinsel yönelim ve benzeri sebeplerle işlenmesi genel bir ceza artırım sebebi olarak öngörülmüştür. ${ }^{41}$

Portekiz'de 2013 değişikliğiyle tehdit, hakaret ve ayrımcılık fiillerinde nefret söylemi cezayı ağırlaştıran neden olarak öngörülmüştür. Ayrıca, kasten öldürme, kasten yaralama ve cinsel saldırının şu karakteristiklere duyulan nefret nedeniyle gerçekleştirilmesi nitelikli hal olarak düzenlenmiştir: ırk, siyasi görüş, din, renk, etnik ya da ulusal orijin, cinsiyet, cinsel yönelim, cinsel kimlik. ${ }^{42}$

Çek Cumhuriyeti'nde 2009 yılında yapılan değişikliklerle ceza kanunu, "siyasi görüşlerinden, uyruklarından, irklarından, inançlarından ya da inanç sahibi olmadıklarından dolay halkın bir kesimine veya bir bireye karşı" şiddet kullanmayı ya da ölümle tehdit etmeyi, sağlığa zarar vermeyi veya ciddi sakatlıklara sebep olmayı -ayrıca- altı aydan üç yıla kadar hapis cezasıyla cezalandırmaktadır. Yine, Kanunun 42. maddesi; hâkimin temel ceza tayininde $\imath r k c ̧ ı$, etnik, dini, sınıf ayrımı ve benzeri nefret saikini göz önünde bulundurmasını buyurmaktadır. Bunun yanında, ceza kanunu özel hükümlerde kasten öldürme, kasten yaralama, hürriyetten yoksun k1lma, işkence, eziyet, mala zarar verme, yağma ve görevi kötüye kullanma suçlarının altında nefret saiki, ağırlaştırıcı neden olarak düzenlenmiştir. Söz konusu düzenlemelerde korunan karakteristikler ise şunlardır: Mağdurun gerçekte olan ya da fail tarafindan öyle sanılan ırk, etnisite, milliyet, politik görüş, din, inanç ve inançsizlığ.$^{43}$

Ingiltere'de 1998 yılında çıkarılan Suç ve Düzensizlik Yasasında kasten yaralama, taciz, tehdit ve mala zarar verme gibi suçların mağdurun sahip olduğu rkka dayanan nefret saiki veya önyarg1 nedeniyle işlenmiş olması halinde cezanın belli miktarlarda ağırlaştırılacağı hükme bağlanmıştır. 2003 Ceza Adaleti Yasasının 'Cezalandırma' başlıklı 12. bölümünde ırk, dini inanç,

\footnotetext{
39 https://www.legislationline.org/documents/id/15753 (sgt. 18.05.2021)

$40 \mathrm{https}$ //www.legislationline.org/topics/country/28/topic/4/subtopic/79 (sgt.19.05.2021)

41 https://www.legislationline.org/documents/id/9032 (sgt.19.05.2021)

42 https://www.legislationline.org/documents/id/15756 (sgt.19.05.2021)

43 https://www.legislationline.org/documents/id/15725 (sgt.19.05.2021)
} 
IIIIIIIIII

cinsel yönelim, engellilik sebeplerine karşı duyulan nefret saiki ile işlenen suçlarda cezaların ağırlaştırılmasını düzenlemektedir. 2008 tarihli Irksal ve Dinsel Nefret Yasası ile de nefret söylemleri cezalandırılmaktadır. ${ }^{44}$

$A B D$ 'de yirminci yüzyılın ortalarından itibaren nefret suçları düzenlemeleri bulunmaktadır. 2007 tarihinde yapılıp 2009'da yürürlüğe giren Nefret Suçlarını Önlemede Yerel Yasaların Güçlendirilmesi Yasası (Matthew Shepard Yasası) nefret suçlarıyla ilgili eyaletler arasındaki farklılıkları asgariye indirmeyi amaçlamış ve federal düzeyde bir standart belirlemiştir. Bu bağlamda, daha önce federal düzeyde belirlenmiş nefret saikleri olan $ı$ rkçılık, dinsel inanç, ten rengi ve etnik köken özelliklerine toplumsal cinsiyet, cinsel kimlik, cinsel yönelim ve engellilik unsurları da ilave edilmiştir. ${ }^{45}$

\section{B. TÜRK HUKUKUNDA NEFRET SUÇU}

\section{ODIHR 2020 Raporunda Türkiye}

Raporda Türkiye'nin, ODIHR'e düzenli olarak nefret suçu verilerini ileten ülkeler arasında yer aldığı belirtilmektedir. İçişleri ve Adalet Bakanlıkları tarafından toplanan bu verilerin kamuoyunun erişimine açılmadığı da ifade edilmektedir. Ayrıca, ülkemizde kolluk görevlilerinin ayrı bir nefret suçu kaydı tutmadıkları da bir gözlem notu olarak ilave edilmiştir. ${ }^{46}$

Önceki yıllardan farklı olarak son raporunda ODIHR, ülkemizle ilgili istatistikleri paylaşırken sadece TCK m. 115'de düzenlenen "İnanç, Düşünce ve Kanaat Hürriyetinin Kullanılmasını Engelleme" suçu ${ }^{47}$ ile 153. maddede yer alan "İbadethanelere Saldırı" suçuna ${ }^{48}$ ilişkin istatistiki verilere yer vermiştir.

44 https://www.legislationline.org/topics/country/53/topic/4/subtopic/79. Ayrıca bkz. Mehmet Zülfü Öner, "İngiltere Hukukunda Nefret Suçları”, TBB Dergisi, S. 116, 2016, s. 85-112.

45 Uğur Ersoy, "Çağımızın Pandemisi: Nefret Suçları", Türkiye Adalet Akademisi Dergisi, Y1l: 9, S. 35, Temmuz 2018, s. 127.

46 https://hatecrime.osce.org/turkey

47 Inanç, düşünce ve kanaat hürriyetinin kullanılmasını engelleme

Madde 115- (1) Cebir veya tehdit kullanarak, bir kimseyi dini, siyasi, sosyal, felsefi inanç, düşünce ve kanaatlerini açılamaya veya değiştirmeye zorlayan ya da bunları açıklamaktan, yaymaktan meneden kişi, bir yıldan üç yıla kadar hapis cezası ile cezalandırılır.

(2) (Değişik: 2/3/2014-6529/14 md.) Dini inancın gereğinin yerine getirilmesinin veya dini ibadet veya ayinlerin bireysel ya da toplu olarak yapılmasının, cebir veya tehdit kullanılarak ya da hukuka aykııı başka bir davranışla engellenmesi hâlinde, fail hakkında birinci fıkraya göre cezaya hükmolunur.

(3) (Ek: 2/3/2014-6529/14 md.) Cebir veya tehdit kullanarak ya da hukuka aykırı başka bir davranışla bir kimsenin inanç, düşünce veya kanaatlerinden kaynaklanan yaşam tarzına ilişkin tercihlerine müdahale eden veya bunları değiştirmeye zorlayan kişiye birinci fikra hükmüne göre ceza verilir.

48 Ibadethanelere ve mezarliklara zarar verme

Madde 153- (1) İbadethanelere, bunların eklentilerine, buralardaki eşyaya, mezarlara, bunların üzerindeki yapılara, mezarlıklardaki tesislere, mezarlıkların korunmasına yönelik 
Önceki yıllarda ise bu iki suçun yanında TCK'nın $122,4^{49} 135,{ }^{50}$ ve $216 . .^{51}$ maddelerine ilişkin veriler de paylaşılmaktaydı. AGİT bu suçların nefret suçu tanımı dışında olduğunu ifade etmiştir. ${ }^{52}$

ODIHR'in paylaştığı resmi bilgilere göre Türkiye'de Nisan 2019-Nisan 2020 tarih aralığında kollukta 79, savcılıkta 248, mahkemelerce mahkûmiyet hükmü verilen 319 olmak üzere resmi kayitlara göre toplam 646 nefret suçu verisi bulunmaktadır. Birkaç ülkeden örnek vermek gerekirse, Almanya'da bu say1 8113, ABD'de 8559, Fransa'da ise 2640 olarak görülmektedir. Türkiye'de veri sayısının düşük görünmesinin sebebi mevzuatımızda nefret suçunun dayandığı norm eksikliği olsa gerektir.

olarak yapılan yapılara yıkmak, bozmak veya kırmak suretiyle zarar veren kişi, bir yıldan dört yıla kadar hapis cezası ile cezalandırılır.

(2) Birinci fikrada belirtilen yerleri ve yapıları kirleten kişi, üç aydan bir yıla kadar hapis veya adlî para cezası ile cezalandırılır.

(3) Birinci ve ikinci fikralardaki fiillerin, ilgili dini inanışı benimseyen toplum kesimini tahkir maksadıyla işlenmesi halinde, verilecek ceza üçte biri oranında artırılır.

49 Nefret ve aytrimcillk

Madde 122- (Değişik: 2/3/2014-6529/15 md.)

(1) Dil, rrk, milliyet, renk, cinsiyet, engellilik, siyasi düşünce, felsefi inanç, din veya mezhep farklılığından kaynaklanan nefret nedeniyle;

a) Bir kişiye kamuya arz edilmiş olan bir taşınır veya taşınmaz malın satılmasını, devrini veya kiraya verilmesini,

b) Bir kişinin kamuya arz edilmiş belli bir hizmetten yararlanmasını,

c) Bir kişinin işe alınmasını,

d) Bir kişinin olağan bir ekonomik etkinlikte bulunmasını,

engelleyen kimse, bir yıldan üç yıla kadar hapis cezası ile cezalandırılır.

50 Kişisel verilerin kaydedilmesi

Madde 135- (1) Hukuka aykırı olarak kişisel verileri kaydeden kimseye bir yıldan üç yıla kadar hapis cezası verilir.

(2) Kişisel verinin, kişilerin siyasi, felsefi veya dini görüşlerine, ırki kökenlerine; hukuka aykırı olarak ahlaki eğilimlerine, cinsel yaşamlarına, sağlık durumlarına veya sendikal bağlantılarına ilişkin olması durumunda birinci fikra uyarınca verilecek ceza yarı oranında artirilır.

51 Halkı kin ve düşmanlığa tahrik veya aşağılama

Madde 216- (1) Halkın sosyal sınıf, ırk, din, mezhep veya bölge bakımından farklı özelliklere sahip bir kesimini, diğer bir kesimi aleyhine kin ve düşmanlığa alenen tahrik eden kimse, bu nedenle kamu güvenliği açısından açık ve yakın bir tehlikenin ortaya çıkması halinde, bir yıldan üç yıla kadar hapis cezası ile cezalandırılır.

(2) Halkın bir kesimini, sosyal sınıf, ırk, din, mezhep, cinsiyet veya bölge farklılığına dayanarak alenen aşağılayan kişi, altı aydan bir yıla kadar hapis cezası ile cezalandırılır.

(3) Halkın bir kesiminin benimsediği dini değerleri alenen aşağılayan kişi, fiilin kamu barışını bozmaya elverişli olması halinde, altı aydan bir yıla kadar hapis cezası ile cezalandırılır.

52 Nefret suçu sayılmayan bu üç suçtan birincisinin aslında ayrımcılık suçu olduğu, ikincisinde nefret saikinin bulunmadığı, halkı kin ve düşmanlığa tahrik veya aşağılamanın ise nefret suçu değil de nefret söylemi kapsamına girdiği şeklinde bir değerlendirme yapılmış olabileceğini tahmin ediyoruz. 
IIIIIIIIIII-

ODIHR yıllık raporlarında, devletlerin gönderdiği resmi veriler dışında sahadan toplanan, sivil toplum kuruluşlarından edinilen 'diğer kaynak' bilgileri de paylaşılmaktadır. Burada, mevzuatta yer almasa da nefret suçu karakteristiklerine göre bir değerlendirme yapılmaktadır. Buna göre Türkiye'de 2019 yılında 13 rrkçı şiddet, 3 anti-semitist şiddet; 16 inanç özgürlüğüne karşı, 58 cinsel kimlik ve cinsel yönelime karşı duyulan nefret temelli şiddet vakaları yaşanmıştır. Toplam vaka sayısı 90'dır. Bu sayıların da gerçek durumu yansıtmadığı kanısındayız. Doğrusu bu tablo, ülkemizde nefret suçu raporlama, veri toplama, farkındalığı artırma, mağdurlara destek olma ve merkezi-yerel yönetim/STK-idare işbirliği içinde projeler geliştirme konusunda yetersizliğin bir sonucudur. Belirtmek gerekir ki, nefret suçları ile mücadeleyi mevzuatına taşımış ve toplumsal duyarlılığı yüksek tutan ülkelerde, sivil toplumun bu suçlar üzerinde titiz bir şekilde durmaları, kamuoyunu bu hususta bilgilendirmeleri önemli ve olumlu bir etki doğurmuştur. ${ }^{53}$

\section{Türk Hukukunda Nefret Suçu Var mı?}

\section{a. Nefret Suçu}

Yukarıda belirtildiği üzere, ODIHR, TCK'da iki yerde nefret suçu öngörüldüğünü 'kabul etmiş̧ir'; bunlar "inanç, düşünce ve kanaat hürriyetinin kullanılmasını engelleme" ile "ibadethanelere ve mezarlıklara zarar verme" suçlarıdır. Aslında bu düzenlemeler de nefret suçu değildir. Düzenlemelerde ODIHR'ın aradığı temel suç kriteri var ise de nefret/düşmanlık/ön yargı saiki eksiktir. Bu saikin hangi karakteristiklere (cinsiyet, cinsel yönelim, din, siyasi görüş, 1rk, etnisite vs.) yöneleceğine dair bir tanımlama bulunmamaktadır. $\mathrm{Bu}$ durumda, Türk hukukunda nefret suçlarına ilişkin doğrudan ve belirli bir ceza normu bulunduğunu söyleyebilmek güçtür.

Ceza Kanunumuzun 122. maddesinde düzenlenen "Nefret ve Ayırımcilık" suçuna gelince; bu düzenleme nefret suçuna değil, ayrımcıllk suçuna ilişkindir. ${ }^{54} 6529$ sayılı Temel Hak ve Hürriyetlerin Geliştirilmesi Amacıyla Çeşitli Kanunlarda Değişiklik Yapılmasına Dair Kanun'un 15. maddesi ile "ayırımcılık" suçu değiştirilerek "nefret ve ayırımcılık" suçu haline getirilmiştir. Burada yapılan, ayrımcılık suçunun temelinde nefret motifinin aranmasıdır. Hatta bu yönüyle suçun uygulama alanı daraltılmıştır. ${ }^{55}$ Zira suç,

53 Ersoy, s. 133.

54 “TCK'nın 122. maddesinin başlı̆̆ "nefret ve ayırımcılık” suçu olarak belirtilmesine karşın TCK da, yukarıda tanımlanan anlamda bağımsız olarak nefret suçu düzenlenmesi yoluna gidilmemiştir. TCK'nın 122. maddesinin sadece nefret saiki ile işlenen ayırımcılık eylemlerini suç olarak düzenlediğini görmekteyiz" (Yargitay 18. CD, 2018/1978 E., 2019/13554 K., 01.10.2019, UYAP)

55 Örneğin AB Türkiye 2020 raporunda, "engelliliğe dayalı ayrımcıllğı̆n suç sayılması için nefret saikiyle hareket edildiğine dair kanıt göstermenin şart koşulduğu Türk Ceza Kanunu gibi AB müktesebatı ile uyumlu olmayan ayrımcı hükümler mevzuatta yer almaya devam 
düzenlemenin eski halinde nefret dışı sebeplerle de işlenebilirken, değişiklik sonucunda yalnızca nefret saikinin etkisi ile işlenebilecektir. Dolayısıyla bu değişiklikle nefret suçu düzenlenmemiş, sadece zaten uygulanması oldukça kısıtlı olan ayrımcılık suçuna ilave bir manevi unsur daha (özel kasıt) getirilmiştir. ${ }^{56} \mathrm{Bu}$ durumu şöyle bir örnekle açılayabiliriz: İnanç gereği tercih edilen bir kıyafete ya da doğrudan o inanca duyulan ön yargının tahrikiyle bir kadını taciz etmek nefret suçu teşkil etmeyecek, ancak bu kişiyi aynı ön yargıdan dolayı işe almamakla ayrımcılık suçu oluşacaktır.

Şu halde Türkiye, AGIT coğrafyasında mevzuatında spesifik bir nefret suçu düzenlemesi olmayan birkaç ülkeden biridir. Bu durum sadece AGİT nezdinde değil, başka uluslararası platformlarda da gündeme gelmektedir. Örneğin AB 2020 Türkiye Raporu'nun "Yargı ve Temel Haklar" başlıklı 23. Faslında bu konuya dikkat çekilmiştir. ${ }^{57}$

2 Mart 2021 tarihinde kamuoyu ile paylaşılan İnsan Hakları Eylem Planı'nın "İfade, Örgütlenme ve Din Özgürlüklerinin Korunması ve Geliştirilmesi" başlıklı 4. amacının "Nefret Söylemi ve Ayrımcılıkla Mücadelede Etkinliğin Artırılması" başlıklı hedef altında öngörülen faaliyetlerden biri de "ayrımcılık ve nefret suçuna ilişkin Türk Ceza Kanunu'nda yeni bir düzenleme" yapılmasıdır. ${ }^{58}$ Bir yıl içinde yapılması planlanan bu değiş̧iklik, ODIHR doktrininde öngörülen çerçevede hayata geçtiği takdirde ciddi bir boşluğu dolduracaktır.

\section{b. Nefret Söylemi}

Çalışmamızın merkezinde nefret suçları yer alsa da, konumuzla yakın ilgisi nedeniyle nefret söylemi bakımından da mevzuatımıza dair birtakım tespitler yapmakta yarar görüyoruz.

etmektedir." şeklinde bir eleştiri bulunmaktadır. https://www.ab.gov.tr/siteimages/trkiye_ raporustrateji_belgesi_2020/turkey_report_30.10.2020.pdf s. 43. (sgt. 20.05.2021)

56 Türay, s. 91.

57 "Daha önceki Komisyon tavsiyelerinde belirtildiği üzere Türkiye, AIHHS'in yanı sıra AB müktesebatı ile uyumlu olarak, cinsel yönelim ve toplumsal cinsiyet kimliği ile ilgili olanlar dâhil, ayrımcılıkla mücadeleye yönelik bir kanunu ivedilikle kabul etmelidir. Türkiye ayrıca, ayrımcılığın genel olarak yasaklanmasını öngören AIHS'nin 12 No.lu Protokolü'nü onaylamalı ve Avrupa Konseyi Irkçılık ve Hoşgörüsüzlüğe karşı Avrupa Komisyonu tavsiyelerini uygulamalıdır. Nefret suçlarına ilişkin mevzuat, uluslararası standartlarla uyumlu değildir ve cinsel yönelim ya da toplumsal cinsiyet kimliğinden kaynaklanan nefret suçlarını kapsamamaktadır. Bilgisayar sistemleri aracıllğıyla işlenen ırkçılık ve yabancı düşmanlığına yönelik fillerin suç sayılmasına ilişkin Avrupa Konseyi Siber Suçlar Sözleşmesi'nin İhtiyari Protokolü hâlen onaylanmamıştır."

https://www.ab.gov.tr/siteimages/trkiye_raporustrateji_belgesi_2020/turkey_ report_30.10.2020.pdf s. 42. (sgt. 20.05.2021)

$58 \mathrm{https}$ ://inhak.adalet.gov.tr/Resimler/SayfaDokuman/432021111837insan-haklariep02-03-202115-14.pdf (sgt. 20.05.2021) 
IIIIIIIIII!

Nefret söylemi ifade ile ortaya çıktığına göre, önce ifadenin suç teşkil ettiği düzenlemelerin neler olduğunu tespit etmek, sonra bunlarda nefret saikinin bir unsur ya da nitelikli hal olarak düzenlenip düzenlenmediğine bakmak gerekir. Elimizde bir ifade suçları kataloğu bulunamamaktadır, ancak CMK'nın 286. maddesinin üçüncü fikrasının bize bu konuda yardımcı olabileceğini düşünüyoruz. Bu düzenlemede, bölge adliye mahkemelerinin genel kuraldan ayrı olarak temyiz edilebilecek kararları belirtilmiştir. Madde gerekçesine göre bu belirleme yapılırken, "ifade özgürlüğü ile doğrudan etkili suçlar esas alınmıştır". ${ }^{59}$ Gerçekten, düzenlemeye bakıldığında silahlı örgüt dışındakilerin ifadeyle işlenebilecek suçlar olduğu görülmektedir.

$\mathrm{Bu}$ kapsamda, Türk Ceza Kanunu'nda yer alan ifade suçları şunlardır: Hakaret (m. 125), Halk arasında korku ve panik yaratmak amaciyla tehdit (m. 213), Suç işlemeye tahrik (m. 214), Suçu ve suçluyu övme (m. 215), Halkı kin ve düşmanlığa tahrik veya aşağılama (m. 216), Kanunlara uymamaya tahrik (m. 217), Cumhurbaşkanına hakaret (madde 299), Devletin egemenlik alametlerini aşağılama (m. 300), Türk Milletini, Türkiye Cumhuriyeti Devletini, Devletin kurum ve organlarını aşağılama (m. 301), Halkı askerlikten soğutma (madde 318). Yine, CMK m. 286'da yer alan terör propagandası suçu da TMK'da düzenlenmiş bir ifade suçudur. Ayrıca, anılan maddede yer almamakla birlikte, tehdit (m. 106), cinsel taciz (m. 105), şantaj (m. 107), kişinin hatırasına hakaret (m. 130) ve müstehcenlik (m. 226) suçları da ifadeyle işlenebilecek suçlardır. Aynı şekilde, 5816 sayılı Atatürk Aleyhine İşlenen Suçlar Hakkında Kanun da bu bağlamda özel ceza normlarına örnek olarak gösterilebilir. ${ }^{60}$

Buraya kadar saydığımız herhangi bir ifade/düşünce/söylem suçunun aynı zamanda ya da nitelikli hal olarak bir nefret söylemi suçu oluşturabilmesi için iki hususun var olması gerekir. Birincisi, bu ifade nefret veya önyarg1 saikiyle kullanılmalı, ikincisi de bu nefret veya önyargı bir kişide ya da grupta bulunan belli karakteristiklerden kaynaklanmalıdır. Bu açıdan söz konusu düzenlemelere bakıldığında, TCK'da sadece $\mathrm{m}$. 125/3-b ve c alt bentleri ${ }^{61}$ ile m. $216^{\prime}$ da $^{62}$ belli karakteristiklerin sayıldığı görülmektedir. Bunlarda da nefret

59 https://www2.tbmm.gov.tr/d27/2/2-2215.pdf (sgt. 20.05.2021)

60 İftira, yalan tanıklık, suç uydurma gibi suçlar da ifade ile işlenebilirse de bu suçların nefret saikiyle işlenmesi nefret söylemine değil nefret suçuna daha uygun düşecektir. Tabii bu durum da nefret saikinin ve belli karakteristiklerin ilgili düzenlemeye dâhil olmasına bağlıdır.

${ }_{61}$ "b) Dini, siyasi, sosyal, felsefi inanç, düşünce ve kanaatlerini açıklamasından, değiştirmesinden, yaymaya çalışmasından, mensup olduğu dinin emir ve yasaklarına uygun davranmasindan dolayı,

c) Kişinin mensup bulunduğu dine göre kutsal sayılan değerlerden bahisle,"

62 “...sosyal sınıf, ırk, din, mezhep, cinsiyet veya bölge farklılığına dayanarak..." 
saiki açıkça düzenlenmiş değildir. Somut olayda bu fiiller nefret söylemi olabileceği gibi, herhangi bir spesifik amaç veya saik gözetmeksizin "genel kasıtla" işlenmiş de olabilir. ${ }^{63}$ Bazen de, kişinin nefret söylemi, muhatabıyla hakaret ilişkisi kurulamadığında büsbütün cezasız da kalabilir. ${ }^{64} \mathrm{O}$ halde mevzuatımızda belirli bir nefret söylemi suçu bulunmamaktadır. Bir nefret söylemi ancak hakaret veya halkı kin ve düşmanlığa tahrik/aşağılama gibi başka bir suçun içine nüfuz ettiği takdirde cezalandırılabilecektir.

Elbette, bir kanunda nefret söylemi başlığ taşıyan bir ceza normunun olmamas1, hemen ve kendiliğinden o kanunda nefret söyleminin sorumluluğa yol açmadığı anlamına gelmez. Ancak yasa koyucu nefret söylemini her durumda cezalandırmak istiyorsa, şerefe karşı suçlarda ve kamu barışına karşı suçlarda daha açık ve belirli düzenlemeler yapmalıdır.

63 Hakaret suçunun genel kasıtla işlenebileceği, özel bir tahkir kastı aranmadığı hakkında bkz; Zeki Hafızoğulları-Muharrem Özen, Türk Ceza Hukuku Özel Hükümler Kişilere Karşı Suçlar, Ankara 2017, s. 232; Nur Centel-Hamide Zafer-Özlem Çakmut, Kişilere Karşı İşlenen Suçlar, İstanbul 2017, s. 255; Veli Özer Özbek, "Şerefe Karş1 Suçlar", Hukuk ve Adalet Eleştirel Hukuk Dergisi, Avukat M. Haldun Karacabey’e Armağan, Yı1: 2, Sayı:5, İstanbul 2005, s. 269. "Halkı kin ve düşmanlığa tahrik veya aşağılama" suçunun manevi unsuru hakkında bkz. Özge Apiş, Halkı kin ve düşmanlığa tahrik veya aşağılama suçları (TCK m. 216), Marmara Üni Doktora Tezi, İstanbul 2017. Yazara göre, her ne kadar madde metninde failin saikine ilişkin özel bir belirleme yok ise de madde gerekçesinde failin kin ve nefrete tahrik bakımından, "sübjektif olarak bu amacı gütmesi” gerektiği ifade edildiğinden, bu suç ancak özel kasıtla işlenebilecek, bu da ancak nefret saiki olabilecektir. (Apiş, s. 151). Suçun kanuniliği ve bunun alt ilkesi olan belirlilik gereğince bu görüşe katılmadığımızı ifade etmeliyiz. Bu konuda ayrıca yazarın şu çalışmasını da dikkate sunmak isteriz: Özge Apiş, "Nefret Suçları Kavramı Kapsamında Halkın Belli Bir Kesimini Alenen Aşağılama Suçunun İHAM Kararları Bakımından Değerlendirilmesi", Antalya Bilim Üniversitesi Hukuk Fakültesi Dergisi, Cilt: 7, Say1: 13, Haziran 2019, Sayfa: 301-346.

"Hakaret fiillerinin cezalandırlmastyla korunan hukuki değer, kişilerin onur, şeref ve saygınlığı olup, bu suçun oluşabilmesi için, davranışın kişiyi küçük düşürmeye matuf olarak gerçekleşmesi gerekmektedir. Bir hareketin tahkir edici olup olmadiğ bazı durumlarda nispi olup, zamana, yere ve duruma göre değişebilmektedir. Kamu görevlileri veya sivil vatandaşa yönelik her türlü ă̆ır eleştiri veya rahatsız edici sözlerin hakaret suçu bağlamında değerlendirilmemesi, sözlerin açıkça, onur, şeref, ve saygınlı̆̆ rencide edebilecek nitelikte somut bir fiil veya olgu isnadını veya sövmek fiilini oluşturması gerekmektedir.

Sanığın, katılana yönelik "senin yerin burası değil, dağda yaşaman lazım, çingene gibisiniz, gecekonduda yaşamışsınız" şeklindeki ifadelerinde geçen "Çingene” sözü, Türk Dil Kurumunun Güncel Sözlüğünde "Hindistan'dan çıktıkları söylenen, dünyanın çeşitli yerlerinde yaşayan bir topluluk" olarak tarif edilmiş olup, sanığın "çingene" ifadesi ile halen ülkemizde kendilerini "roman" olarak nitelendiren ve Avrupa'dan Türkiye'ye göçetmiş vatandaşlarımızı kast etmesi karşısında; bu sözlerin katılanın onur, şeref ve saygınlı̆̆ını rencide edici boyutta olmaması nedeniyle, hakaret suçunun unsurlarının oluşmadiğı gözetilmeden, mahkûmiyet kararl verilmesi..." (2015/997 E., 2015/580 K., 27.04.2015, UYAP) 
IIIIIIIIII!

\section{SONUÇ}

Türkiye'nin sosyal dokusu ve tarihi birikimi; çok farklı inanış, tercih ve yaşam tarzlarının huzur içinde birlikte yaşamasına güçlü bir zemin olarak görülmelidir. Hukuk bu çoğulcu mirasın teminatı olarak rol almalı, nefret suçlarına ilişkin belirli kurallar içermelidir.

TCK'da yapılacak bir düzenleme genel bir artırım nedeni şeklinde olabileceği gibi, bazı özel hükümlerde cezayı artıran nitelikli hal biçiminde de ortaya çıkabilir. Diğer bir yol da müstakil bir nefret suçları kanunu hazırlamaktır. Hangi yöntem seçilirse seçilsin önemli olan; kişilerin kaderinde, doğasında, kimliğinde ya da öz tercihlerinde bulunan unsurlara yönelik nefret, ön yarg1 veya düşmanlık saikli suçları 'gören' ve niteleyen bir normun bulunmasıdır.

Önereceğimiz yöntem, TCK’nın 122. maddesinin başlığına uygun şekilde nefret suçunu da içerecek şekilde değiştirilmesi, ilave edilecek fikralarla nefret saikinin tanımı, nefret mağdurunda korunacak karakteristik özellikler ve hangi suçlarda ne kadar ceza artırımı yapılacağının belirtilmesidir. Bu bağlamda kasten öldürme, kasten yaralama, işkence, eziyet, cinsel dokunulmazlığa karşı suçlar, tehdit, kişiyi hürriyetinden yoksun kılma, yağma, mala zarar verme, inanç, düşünce ve kanaat hürriyetinin kullanılmasını engelleme, ibadethanelere ve mezarlıklara zarar verme fiillerinin nefret saikiyle işlenmesi cezay1 ağırlaştıran nitelikli bir hal olarak kabul edilebilir. Bu tarz bir düzenleme, ilgili her maddede değişiklik yapmaktan daha kullanışı olacaktır. Çeşitli suçları "özel kasıt" paydasında buluşturan müstakil düzenleme olarak Kanun'un insanlığa karşı suçlar başlıklı 77. madde yazımı örnek alınabilir.

TCK'nın 'kamu barışına karşı suçlar' bölümüne 'nefret söylemi' hakkında bir düzenleme getirilmesi de hem nefret suçu ile nefret söylemi arasındaki farkı ortaya koymuş olacak hem de bu tarz söylemlere karşı hukuki niteleme noktasında uygulamada karşılaşılan tereddütleri giderecektir. Aynı şekilde, hakaret suçuna ilişkin TCK 125. madde düzenlemesi de bir nitelikli hal olarak nefret söylemini belirli ve açık şekilde içermelidir.

Nefret saikiyle işlenen bir fiilin toplum üzerindeki mevcut ve muhtemel etkileri düşünüldüğünde, bu fiilin spesifik bir saik ya da amaç gütmeksizin ("genel kasıtla") işlenen herhangi bir haline göre çok daha tehlikeli olduğu kuşkusuzdur. Bu tehlikeyi önlemek için ciddi ve kararlı bir tavır alınması zorunludur. Bu kapsamda kanunla korunacak karakteristik özelliklerin hangileri olacağ1 konusunda uluslararası toplum ile ulusal dinamikler arasında hukuksal bir denge arayışı önemlidir. Ancak bu tarz düzenlemelerin toplumun tamamını ve ülkedeki her 'insanı' kuşatma iddiasında olduğu unutulmamalıdır. Aksi takdirde nefret suçunun doğası ve kök sebepleri ile mücadele eksik kalacaktır.

Nefret suçlarını önlemenin en etkili yolu toplumsal duyarlılık ve kamuoyu farkındalığıdır. Bu kapsamda küçük yaşlardan itibaren tolerans, eşitlik, insan 
onuru ve demokrasi kavramlarının eğitim müfredatında yer alması büyük önem taşımaktadır. Yine bu amacın bir parçası olarak, nefret suçu istatistikleri AGiT ile paylaşıldığı gibi, mutat olarak kamuoyunun erişimine de açılmalıdır. Nefret suçlarının önlenmesi için raporlama, istatistiki değerlendirme ve bunlardan sonuç çıkarmanın önemi inkâr edilemez. Bu nedenle henüz kolluk aşamasında nefret suçu kayıtlarının tutulması ve bu aşamada mağdurların hukuk düzenine ve topluma küsmemesini sağlayacak onarıcı adalet uygulamalarının geliştirilmesi, bu suçla mücadele ve önleyici politikaların geliştirilmesi bakımından büyük önem taşımaktadır.

\section{KAYNAKLAR}

Apiş, Özge, Halkı kin ve düşmanlığa tahrik veya aşağılama suçları (TCK m. 216), Marmara Üni. Doktora Tezi, İstanbul 2017.

Apiş, Özge, "Nefret Suçları Kavramı Kapsamında Halkın Belli Bir Kesimini Alenen Aşağılama Suçunun İHAM Kararları Bakımından Değerlendirilmesi”, Antalya Bilim Üniversitesi Hukuk Fakültesi Dergisi, Cilt: 7, Sayı: 13, Haziran 2019.

Aytekin İnceoğlu, Asuman, "Nefret Suçu Kavramı ve Türk Ceza Mevzuatı Açısından Değerlendirilmesi", Nefret Söylemi velveya Nefret Suçları, Der: Yasemin İnceoğlu, İstanbul 2012.

Bayraktar, Köksal, "Nefret ve Ayrımcılık Suçu”, Yeditepe Üniversitesi Hukuk Fakültesi Dergisi, Cilt: XIII, Say1: 1, Y11: 2016.

Centel, Nur-Zafer, Hamide-Çakmut, Özlem, Kişilere Karşı İşlenen Suçlar, İstanbul 2017.

Civelek, Jale, "Helsinki Son Senedi, Paris Şartı ve AGIT", Avrupa Araştırmaları Dergisi, C. 14 S. 12, 2006.

Demir, Sertif, "Dünden Bugüne Avrupa Güvenlik ve İşbirliği Teşkilatı", Güvenlik Stratejileri Dergisi, 6/11, 2010.

Demirbaş, Timur, "Nefret Söylemi ve Nefret Suçları", Dokuz Eylül Üniversitesi Hukuku Fakültesi Dergisi, Prof. Dr. Şeref ERTAŞ’a Armağan, Cilt:19, Y11: 2017.

Ersoy, Uğur, "Çağımızın Pandemisi: Nefret Suçları", Türkiye Adalet Akademisi Dergisi, Y11: 9, S. 35, Temmuz 2018

Gül, Cengiz-Çakan, Seher, "AİHM Kararları Işı̆̆ında Nefret, Şiddet Ve Müstehcen İçerikli Söylemler Bakımından İfade Özgürlüğünün Sinırlandırılması", ERÜHFD, C. XIII, S. 1, 2018.

Hafızoğulları Zeki-Özen, Muharrem, Türk Ceza Hukuku Özel Hükümler Kişilere Karşı Suçlar, Ankara 2017.

Karan, Ulaş, "Nefret Suçlarından Ne Anlıyoruz?", Nefret Suçları ve Nefret Söylemi, Hrant Dink Vakfı Yayınları, İstanbul 2010. 
IIIIIIIIII!

Küzeci, Elif, “AİHS'in 10. Maddesi Işığında Nefret İçerikli ve Irkçı Nitelikteki Düşünce Açıklamaları", TBB Dergisi, S. 71, Temmuz 2007.

Öner, Mehmet Zülfü, "İngiltere Hukukunda Nefret Suçları”, TBB Dergisi, S. 116, 2016.

Özbek, Veli Özer, "Şerefe Karşı Suçlar", Hukuk ve Adalet Eleştirel Hukuk Dergisi, Avukat M. Haldun Karacabey’e Armağan, Yı1: 2, Say1:5, İstanbul 2005.

Özbey, Özcan, “Avrupa İnsan Hakları Sözleşmesi Işı̆̆ında İfade Özgürlüğü Kısitlamaları”, Ankara Üniversitesi Hukuk Fakültesi Dergisi, S. 62, May1s 2013.

Serim Çiçek, Gökçe, Türk Ceza Kanunu'nda Nefret ve Ayrımcılık Suçu, Ankara 2021.

Sınar, Hasan, "Türk Hukukunda Nefret Suçlarına İlişkin Yasal Düzenleme Çalışmaları", Marmara Üniversitesi Hukuk Fakültesi Hukuk Araştırmaları Dergisi, 19 / 2, Aralık 2013.

Türay, Aras, "Nefret Söylemi ve İfade Özgürlüğü Arasındaki İlişkiye Yönelik Görüşlerin Kısa Bir Değerlendirmesi”, Suç ve Ceza Dergisi, 2018/2.

Uygun, Oktay, “Nefret İfadesi ve İfade Özgürlügü̈”, Galatasaray Üniversitesi Hukuk Fakültesi Dergisi, C. 5 sayı. 1, Ocak 2008.

Weber, Anne, Nefret Söylemi, Çev: Metin Çulhaoğlu, Avrupa Konseyi Yayınları, 2009.

\section{Kurumsal yayınlar:}

Combating Hate Crimes in the OSCE Region, An Overview of Statistics, Legislation and National Initiatives, OSCE/ODIHR, Warsaw 2005.

Hate Crimes in the OSCE Region-Incidents and Responses, Annual Report for 2007, OSCE/ODIHR, Warsaw 2008.

Hate Crime Laws: A Practical Guide, OSCE/ODIHR, Warsaw 2009.

Preventing and Responding to Hate Crimes, A resource guide for NGOs in the OSCE region, OSCE/ODIHR, Warsaw 2009.

Freedom of Expression and Hate Speech, OSCE/ODIHR, Skopje 2013.

Prosecuting Hate Crimes, OSCE/ODIHR, Warsaw 2014.

Hate Crime Recording and Data Collection Practice Across the EU, European Union Agency for Fundamental Rights, Luxembourg 2018.

Understanding the Needs of Hate Crime Victims, OSCE/ODIHR, Warsaw 2020 . 


\section{Çevrimiçi kaynaklar:}

http://www.osce.org/mc/22775

https://www.osce.org/whatistheosce/factsheet

https://www.coe.int/en/web/european-commission-against-racism-andintolerance/ecri-standards

https://rm.coe.int/ecri-general-policy-recommendation-no-7-revised-onnational-legislatio/16808b5aae

https://rm.coe.int/ecri-general-policy-recommendation-no-15-on-combatinghate-speech/16808b5b01

https://hatecrime.osce.org/odihrs-capacity-building-efforts

https://www.osce.org/files/f/documents/d/9/40695.pdf

https://hatecrime.osce.org/

https://hatecrime.osce.org/civilsociety

https://hatecrime.osce.org/infocus/2019-hate-crime-data-frequently-askedquestions

https://hatecrime.osce.org/switzerland

https://www.legislationline.org/legislation/section/legislation/topic/79/ country $/ 30$

https://www.legislationline.org/topics/country/41/topic/4/subtopic/79

https://www.legislationline.org/documents/id/15753

https://www.legislationline.org/topics/country/53/topic/4/subtopic/79

https://www.legislationline.org/topics/country/28/topic/4/subtopic/79

https://www.legislationline.org/documents/id/9032

https://www.legislationline.org/documents/id/15756

https://www.legislationline.org/documents/id/15725

https://hatecrime.osce.org/turkey

https://www.ab.gov.tr/siteimages/trkiye_raporustrateji_belgesi_2020/turkey_ report_30.10.2020.pdf

https://inhak.adalet.gov.tr/Resimler/SayfaDokuman/432021111837insanhaklari-ep02-03-202115-14.pdf 
108 